Prepared in cooperation with the U.S. Department of the Navy, Navy Region Northwest

\title{
Nitrogen Species in Soil, Sediment, and Ground Water at a Former Sewage-Treatment Wastewater Lagoon: Naval Air Station Whidbey Island, Island County, Washington
}

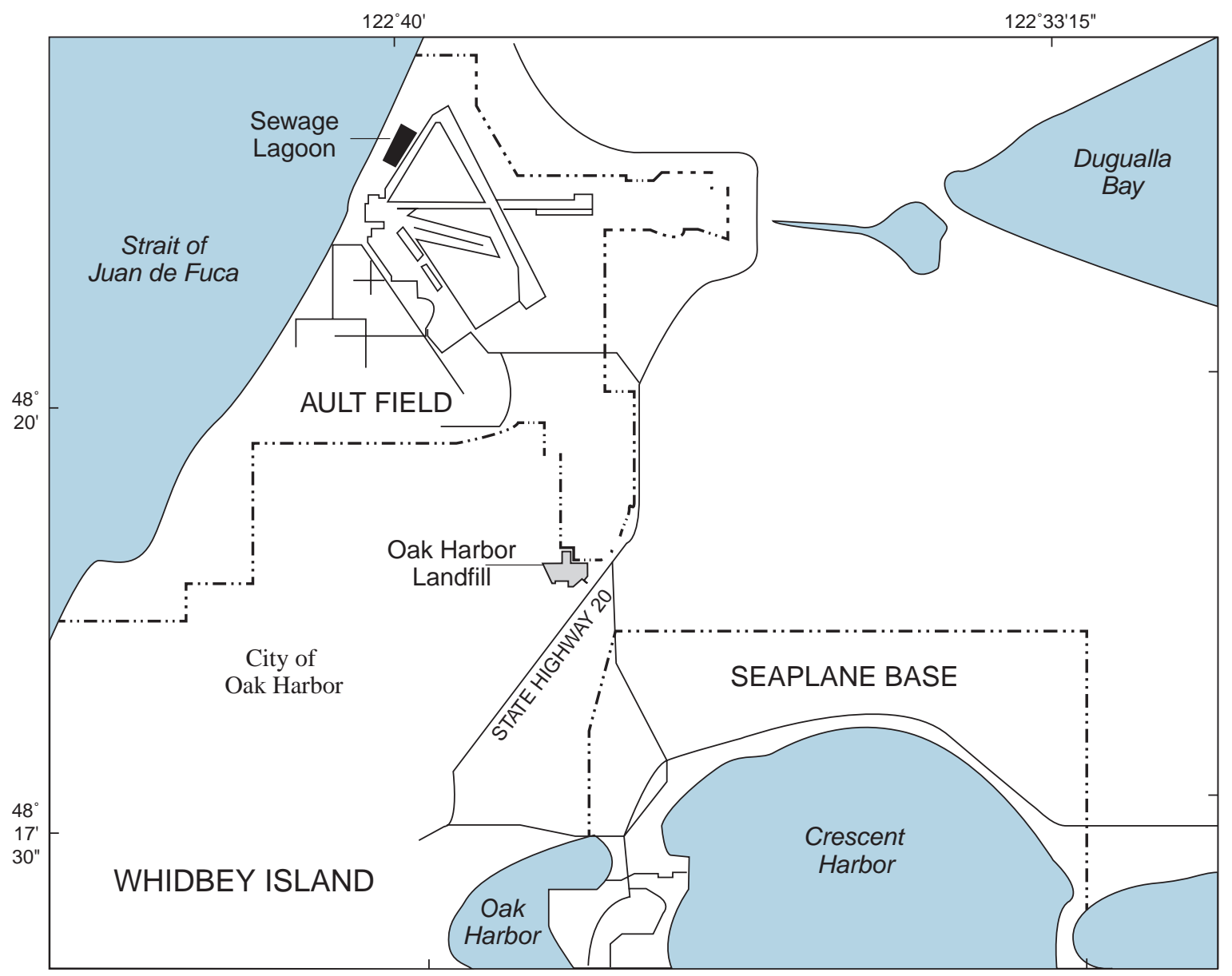

Scientific Investigations Report 2007-5075 



\section{Nitrogen Species in Soil, Sediment, and Ground Water at a Former Sewage-Treatment Wastewater Lagoon: Naval Air Station Whidbey Island, Island County, Washington}

By S.E. Cox, R.S. Dinicola, and R.L. Huffman

Prepared in cooperation with the U.S. Department of the Navy, Navy Region Northwest

Scientific Investigations Report 2007-5075 


\title{
U.S. Department of the Interior DIRK KEMPTHORNE, Secretary
}

\author{
U.S. Geological Survey \\ Mark D. Myers, Director
}

\section{U.S. Geological Survey, Reston, Virginia: 2007}

For product and ordering information:

World Wide Web: http://www.usgs.gov/pubprod

Telephone: 1-888-ASK-USGS

For more information on the USGS--the Federal source for science about the Earth, its natural and living resources, natural hazards, and the environment:

World Wide Web: http://www.usgs.gov

Telephone: 1-888-ASK-USGS

Any use of trade, product, or firm names is for descriptive purposes only and does not imply endorsement by the U.S. Government.

Although this report is in the public domain, permission must be secured from the individual copyright owners to reproduce any copyrighted materials contained within this report.

Suggested citation:

Cox, S.E., Dinicola, R.S., and Huffman, R.L., 2007, Nitrogen species in soil, sediment, and ground water at a former sewage-treatment wastewater lagoon: Naval Air Station Whidbey Island, Island County, Washington: U.S. Geological Survey Scientific Investigations Report 2007-5075, 14 p. 


\section{Contents}

Abstract
Introduction
Purpose and Scope
Description of Study Area
Grounple and Data Collection and Analysis
Ground-Water Quality
Nitrogen in Soils and Sediment
Sumsessment of Potential for Ground-Water Contamination and Conclusions
Acknowledgments
References Cited

\section{Figures}

Figure 1. Map showing location of the former sewage lagoon, Naval Air Station Whidbey Island, Island County, Washington

Figure 2. Map showing location of drive-point wells, soil and sediment sampling sites, and water-level altitudes measured August 10, 2006 at the former sewage lagoon, Naval Air Station Whidbey Island, Washington

\section{Tables}

Table 1. Construction and water-level data for drive-point wells installed at the former sewage lagoon, Naval Air Station Whidbey Island, Washington, June and August 2006

Table 2. Ground-water quality data collected from drive-point wells at the former sewage lagoon at Naval Air Station Whidbey Island, Washington, June and August 2006

Table 3. Nitrogen and organic carbon concentrations in composite soil and sediment samples collected and analyzed by the U.S. Navy at the former sewage lagoon, Naval Air Station Whidbey Island, Washington, June 2006 


\section{Conversion Factors, Datums, Abbreviations and Acronyms}

Conversion Factors

\begin{tabular}{lcl}
\hline Multiply & By & To obtain \\
\hline inch (in.) & 2.54 & centimeter $(\mathrm{cm})$ \\
inch (in.) & 25.4 & millimeter $(\mathrm{mm})$ \\
foot (ft) & 0.3048 & meter $(\mathrm{m})$ \\
mile (mi) & 1.609 & kilometer $(\mathrm{km})$ \\
inch per year (in/yr) & 2.54 & centimeter per year $(\mathrm{cm} / \mathrm{yr})$ \\
pounds per acre (lb/acre) & 1.121 & kilograms per hectare $(\mathrm{kg} / \mathrm{ha})$ \\
\hline
\end{tabular}

Temperature in degrees Celsius $\left({ }^{\circ} \mathrm{C}\right)$ may be converted to degrees Fahrenheit $\left({ }^{\circ} \mathrm{F}\right)$ as follows:

$$
{ }^{\circ} \mathrm{F}=\left(1.8 \times^{\circ} \mathrm{C}\right)+32
$$

Temperature in degrees Fahrenheit $\left({ }^{\circ} \mathrm{F}\right)$ may be converted to degrees Celsius $\left({ }^{\circ} \mathrm{C}\right)$ as follows:

$$
{ }^{\circ} \mathrm{C}=\left({ }^{\circ} \mathrm{F}-32\right) / 1.8
$$

Specific conductance is given in microsiemens per centimeter at 25 degrees Celsius $(\mu \mathrm{S} / \mathrm{cm}$ at $\left.25^{\circ} \mathrm{C}\right)$.

Concentrations of chemical constituents in water are given either in milligrams per liter (mg/L) or micrograms per liter ( $\mu \mathrm{g} / \mathrm{L})$.

Datums

Vertical coordinate information is referenced to the National Geodetic Vertical Datum of 1929 (NGVD 29).

Horizontal coordinate information is referenced to the North American Datum of 1983 (NAD 83).

Altitude, as used in this report, refers to distance above the vertical datum.

Abbreviations and Acronyms

\begin{tabular}{ll}
\hline Abbreviations and Acronyms & Meaning \\
\hline LIDAR & Light Detection and Ranging \\
MCL & maximum contaminant level \\
NAWSI & Naval Air Station Whidbey Island \\
NWQL & National Water Quality L aboratory \\
TOC & total organic carbon \\
USEPA & U.S. Environmental Protection A gency \\
USGS & U.S. Geological Survey \\
\hline
\end{tabular}




\title{
Nitrogen Species in Soil, Sediment, and Ground Water at a Former Sewage-Treatment Wastewater Lagoon: Naval Air Station Whidbey Island, Island County, Washington
}

\author{
S.E. Cox, R.S. Dinicola, and R.L. Huffman
}

\section{Abstract}

The potential for contamination of ground water from remnant sewage sludge in re-graded sediments of a deconstructed sewage-treatment lagoon was evaluated. Ground-water levels were measured in temporary drivepoint wells, and ground-water samples were collected and analyzed for nutrients and other water-qual ity characteristics. Composite soil and sediment samples were collected and analyzed for organic carbon and nitrogen species. M ultiple lines of evidence, including lack of appreciable organic matter in sediments of the former lagoon, agronomic analysis of nitrogen, the sequestration of nitrogen in the developing soils at the former lagoon, and likely occurrence of peat deposits within the aquifer material, suggest that the potential for substantial additions of nitrogen to ground water beneath the former sewage lagoon resulting from remnant sewage sludge not removed from the former lagoon are small.

Concentrations of nitrogen species measured in ground-water samples were small and did not exceed the established U.S. Environmental Protection A gency's maximum contaminant levels for nitrate (10 milligrams per liter). Concentrations of nitrate in ground-water samples were less than the laboratory reporting limit of 0.06 milligram per liter. Seventy to 90 percent of the total nitrogen present in ground water was in the ammonia form with a maximum concentration of 7.67 milligrams per liter. Concentrations of total nitrogen in ground water beneath the site, which is the sum of all forms of nitrogen including nitrate, nitrite, ammonia, and organic nitrogen, ranged from 1.15 to 8.44 milligrams per liter. Thus, even if all forms of nitrogen measured in ground water were converted to nitrate, the combined mass would be less than the maximum contaminant level. Oxidation-reduction conditions in ground water beneath the former sewage lagoon were reducing. Given the abundant supply of ambient organic carbon in the subsurface and in ground water at the former lagoon, any nitrate that may leach from residual sludge and be transported to ground water with recharge is expected to be quickly denitrified or transformed to nitrite and ammonia under the strongly reducing geochemical conditions that are present.
Concentrations of organic carbon, the primary constituent of sewage sludge, in sediments of the former sewage lagoon were less than 1 percent, indicating a near absence of organic matter. The amount of total nitrogen present in the sediments at the former sewage lagoon was only about 25 percent of the amount typically present in developed agricultural soils. The lack of substantial carbon and nitrogen in sediments of the former sewage lagoon indicates that surficial sediments of the former lagoon are essentially devoid of residual sewage sludge. The largest concentration of total nitrogen measured in soil samples from the former sewage lagoon (330 milligrams per kilogram) was used to calculate an estimate of the amount of nitrogen that might be leached from residual sewage sludge by recharge. During the first two years following deconstruction of the former sewage lagoon, the concentration of total nitrogen in recharge leachate might exceed 10 milligrams per liter but the recharge leachate would not likely result in substantial increases in the nitrate concentration in ground water to concentrations greater than the drinkingwater maximum contaminant level of 10 milligrams per liter.

\section{Introduction}

B etween A pril 2004 and September 2005, the unused sewage-treatment lagoon at $\mathrm{N}$ aval $\mathrm{A}$ ir Station W hidbey Island (NA SW I), Island County, Washington, was deconstructed and the site re-graded to conditions matching the surrounding area. Sewage sludge is composed primarily of partially decomposed organic matter and can be a source of contaminants such as nitrogen as further decay releases nitrogen bound in organic forms. A $n$ evaluation of the potential for contamination of ground water from any residual sewage sludge not removed during the deconstruction and remaining in the re-graded sediments needs to be completed as part of the closure process for the former sewage lagoon.

The sewage treatment lagoon was constructed in 1972 between the beach frontage road al ong the Strait of J uan de Fuca and the aircraft taxiway of A ult Field (fig. 1). Four aerators were located near the southern end of the lagoon. 

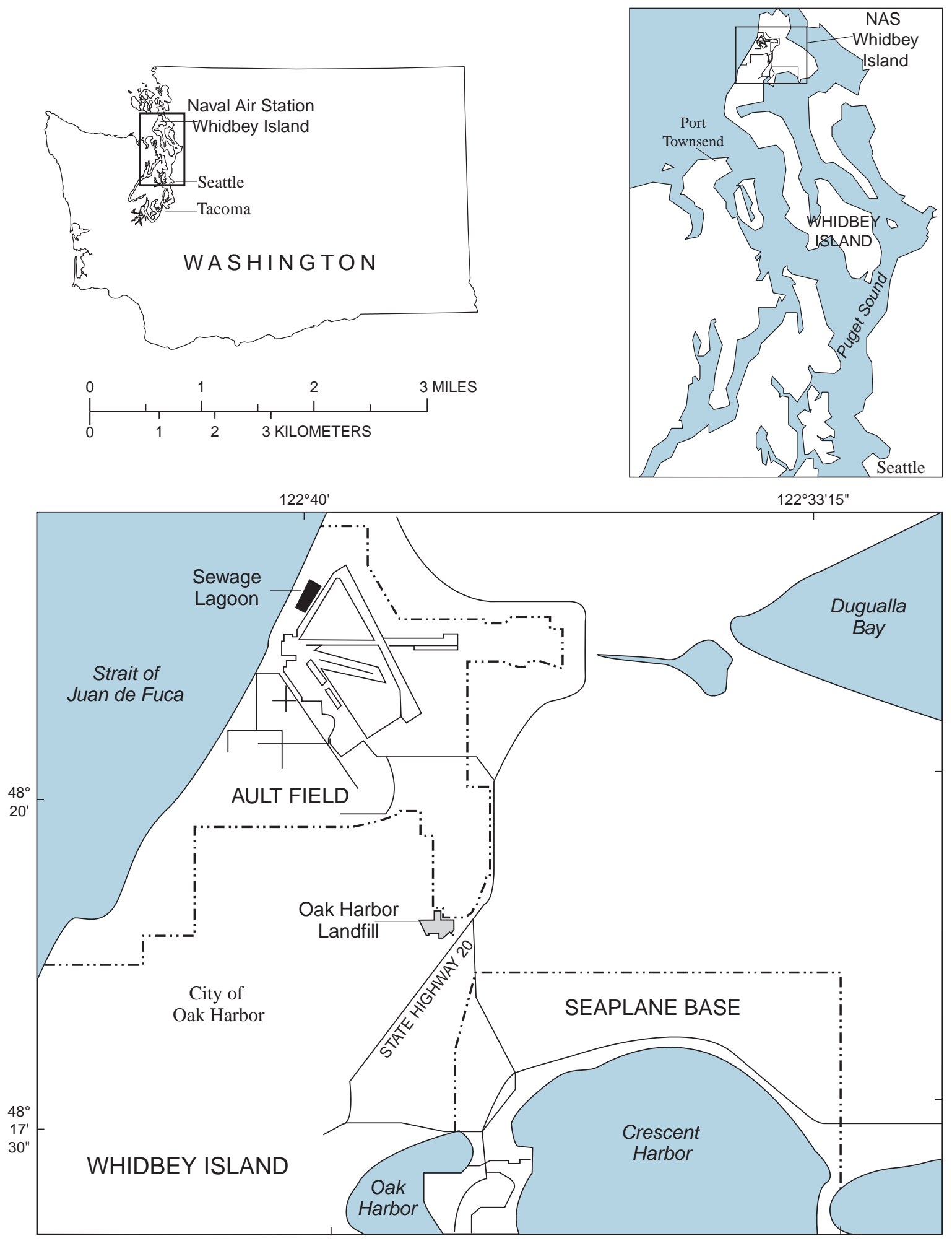

Figure 1. Location of the former sewage lagoon, Naval Air Station Whidbey Island, Island County, Washington. 
The 17-acre lagoon measured about 1,500 $\times 500 \mathrm{ft}$ and was constructed above grade using rip-rap faced earthen berms to a height of $6 \mathrm{ft}$. The bottom of the lagoon was lined with a synthetic liner covered with 6-24 in. of native fill, consisting mostly of sand. The lagoon was an integral part of NA SW I's wastewater-treatment facility until a more modern type of sewage-treatment plant utilizing a sequencing-batch reactor was built in 1998.

A Ithough the lagoon was unused after 1998, it remained filled with water and the thickness of sludge at the bottom of the lagoon ranged from 6 to 33 in. until the following deconstruction steps began in A pril 2004:

- The lagoon was drained from about $6 \mathrm{ft}$ of water to about $3 \mathrm{ft}$.

- A floating dredge removed sludge from the lagoon bottom, and the sludge was dewatered using mobile centrifuges and trucked to a landfill for disposal.

- Remaining water was drained from the lagoon.

- Residual lagoon sludge was allowed to air dry, and was removed along with the top $2 \mathrm{in}$. of sand.

- Synthetic liner was removed, berms were broken down, and the former lagoon was graded to promote drainage.

- Site was hydro-seeded with native grass seed (completed October 2005).

Initial measurements of total $\mathrm{K}$ jehdahl nitrogen concentrations ranged from 177 to $8,700 \mathrm{mg} / \mathrm{kg}$ in soil samples collected from the re-graded sediments in the former sewage lagoon in A ugust 2005. The median concentration for the 15 individual soil samples was $283 \mathrm{mg} / \mathrm{kg}$ (M att J abloner, Naval Engineering Facilities Command Northwest, written commun., J anuary 4, 2006). A ncillary data such as location of sample-collection sites, sampling depth, and wetweight or dry-weight were not reported with this data. Large concentrations, greater than $1,000 \mathrm{mg} / \mathrm{kg}$, measured in 2 of the 15 soil samples prompted concerns regarding potential for contamination of ground water from residual sewage sludge remaining at the former lagoon.

The U.S. Environmental Protection A gency (USEPA), which has regulatory oversight at this installation, considers the former lagoon site to fall under the classification of a biosolids land-application site wherein the surficial material is considered equivalent to applied biosolids. A site-specific evaluation of the potential release and transport of nutrients and possible contamination of ground water is important for final regulatory closure of this site.

\section{Purpose and Scope}

This report describes the characterization of nitrogen concentrations in near-surface soils and shallow ground water at the former sewage lagoon at $\mathrm{N}$ aval $\mathrm{A}$ ir Station W hidbey Island, Washington, and presents an evaluation of the potential for contamination of ground water from nitrogen released from residual sewage sludge. The U.S. Geological Survey (USGS) installed nine temporary direct-push wells to collect water-level data and ground-water samples for analyses of nutrient concentrations and other water-qual ity characteristics. The U.S. N avy collected composite soil samples for analyses of organic carbon and nitrogen species during J une 2006.

\section{Description of Study Area}

Naval A ir Station W hidbey Island (NA SW I), is located on W hidbey Island in Island County, Washington, at the north end of the Puget Sound and on the eastern extent of the Strait of J uan de Fuca. (fig. 1). The NA SWI lies in a low-gradient valley along the western shore of W hidbey Island. The altitude of land surface over most of the runway area that comprises the air station ranges from 20 to $40 \mathrm{ft}$ above sea level.

W hidbey Island has a temperate marine climate characterized by warm, dry summers and cool, wet winters. $M$ ean annual temperature is about $50^{\circ} \mathrm{F}$. J anuary is the coolest month and A ugust the warmest. $M$ ean annual precipitation is about $19 \mathrm{in} / \mathrm{yr}$ in the area of the NA SWI. Ground-water recharge on Whidbey Island has been estimated to be $11.8 \mathrm{in} /$ yr (Vaccaro and others, 1998). There are no perennial streams draining the study area and most surface-water runoff drains to wetlands near the runways at A ult Field. Wetland areas are depicted near the upgradient runway areas on $71 / 2$-minute topographic maps of the area. Surface indications of two buried stormwater drainage lines crossing from the taxi-way to the beach area were observed.

The hydrogeologic framework of W hidbey Island and NA SWI is predominantly composed of Pleistocene age glacial drift deposits. A t land surface, these deposits typically include tills consisting of a dense-compact mixture of silts, clay, sands, gravels; fluvial outwash deposits consisting of variously sorted deposits of coarse-grained sands, silts, and gravels; and interglacial deposits of silts and clay. N ear A ult Field, the surficial sediments are composed of clay, silt, and silty fine sand (URS Team, 1993). Depth to ground water beneath the former sewage lagoon is approximately $12 \mathrm{ft}$, and the general direction of ground-water flow typically is towards the coastline of Puget Sound (Sapik and others, 1988). 
Peat and peat-soils, while not common on Whidbey Island, are present in low-lying coastal areas including the vicinity of the former sewage lagoon. Soils in the vicinity of the former sewage lagoon were mapped as Rifle or Tanawax peat soils (N ess and Richins, 1958). The largest peat deposit on the Island is near Cranberry Lake located 1.25 mi north of Ault Field (Riggs, 1958).

The former rectangular shaped sewage lagoon was located between the A ult Field taxiway and the adjacent shoreline road al ong the Strait of J uan de Fuca. The altitude of land surface upgradient of the former sewage lagoon ranges from 20 to $25 \mathrm{ft}$. The altitude of land surface immediately downgradient of the former sewage lagoon typically is about $15 \mathrm{ft}$. There is about $200 \mathrm{ft}$ of irregular surface between the roadway and beach area. Concrete rip-rap has been placed over portions of the upper beach area.

\section{Sample and Data Collection and Analysis}

Water-level measurements and water-sample collection, processing, and field analysis were performed in accordance with applicable USGS procedures (U.S. Geological Survey, 1997-2006). Soil samples were collected by the U.S. N avy in J une 2006 and analyzed to determine the dry-weight concentration of organic carbon and nitrogen species. Soil samples were collected using non-contaminating materials, and surficial plant litter material was removed from the samples. A dditional details concerning soil sampling are available from the U.S. N avy (M att J abloner, written commun., September 8, 2006).

Nine temporary drive-point wells (fig. 2) were installed at the study site to measure ground-water levels and collect water-qual ity samples in J une-A ugust 2006. Wells were located along three transects that were approximately perpendicular to the anticipated direction of ground-water flow toward the beach. Four wells were installed along the approximate center line of the former lagoon, three wells were installed upgradient of the lagoon, and two wells were installed downgradient of the lagoon. Buried rip-rap did not allow installation of additional downgradient wells near the beach area.

The drive-point wells were constructed using Schedule 800.5 in black-iron pipe. The lower ends of the pipe were crimped closed and a series of 20 to 25 1/8th in. diameter holes were drilled to allow ground water entry into the pipe. The pipes were manually driven into the ground to the depth just below the water table using a slide hammer. Wells were developed using a surge block and peristaltic pump. A fter a drive-point well was driven into position, the casing was filled with clean water and a surge-block was used to move water through the well perforations. A peristaltic pump was then used to extract more than 10 times the volume of water placed in the well during the surge-block development process.

Depth to ground water below a measuring point at the top of the exposed casing was measured in the wells using a steel tape. The relative altitude of water-level measuring points for each well were determined using a Surveyors level and a reference altitude obtained from Light Detection and Ranging ( $L i D A R$ ) imaging of land-surface altitude at well LSD2. The LiDA R data were obtained in A ugust 2001 and shows the general outline of the former sewage lagoon area. Figure 2 shows the LiDAR image of the former sewage lagoon and the locations of the drive-point wells and soil and sediment sampling sites. The surveying closure error, taken as the difference in altitude of the starting reference point following seven changes of instrument location, was $0.03 \mathrm{ft}$.

A fter measuring depth to water, ground-water samples were collected with a low-flow peristaltic pump and singleuse polyethylene tubing. Samples were collected after approximately three casing-volumes of water were purged from the wells and after allowing specific conductance and dissolved oxygen (DO) to stabilize to within 5 percent, and $0.3 \mathrm{mg} / \mathrm{L}$, respectively. The geochemical measurements and concentrations analyzed for water samples collected from wells included nutrients (filtered total nitrogen, filtered nitrite plus nitrate, filtered nitrite, filtered orthophosphate), organic carbon, filtered concentrations of chloride, ferrous iron (II), and carbon dioxide. A $0.45 \mu \mathrm{m}$ membrane filter was used to prepare filtered samples. Specific conductance was measured using a sensor that was checked with a standard reference solution. Dissolved-oxygen concentrations were measured using a $0-1 \mathrm{mg} / \mathrm{L}$ CHEM ets Rhodazine-DTM colorimeteric ampoules (manufactured by CHEM etrics, Inc., Calverton, Va.). The ampoules were filled directly from the sampling tube after well purging was complete. Ferrous iron (II) concentrations were measured in the field using a colorimetric 1,10 phenanthroline indicator method and $\mathrm{H}$ ach M odel 2010 spectrophotometer according to $\mathrm{H}$ ach analytical number 8146 (Hach Company, 1998). Dissolved carbon dioxide concentrations were measured in the field using Titret-Sodium hydroxide titrant with a pH indicator (manufactured by CHEM etrics, Inc., Calverton, Va.). 


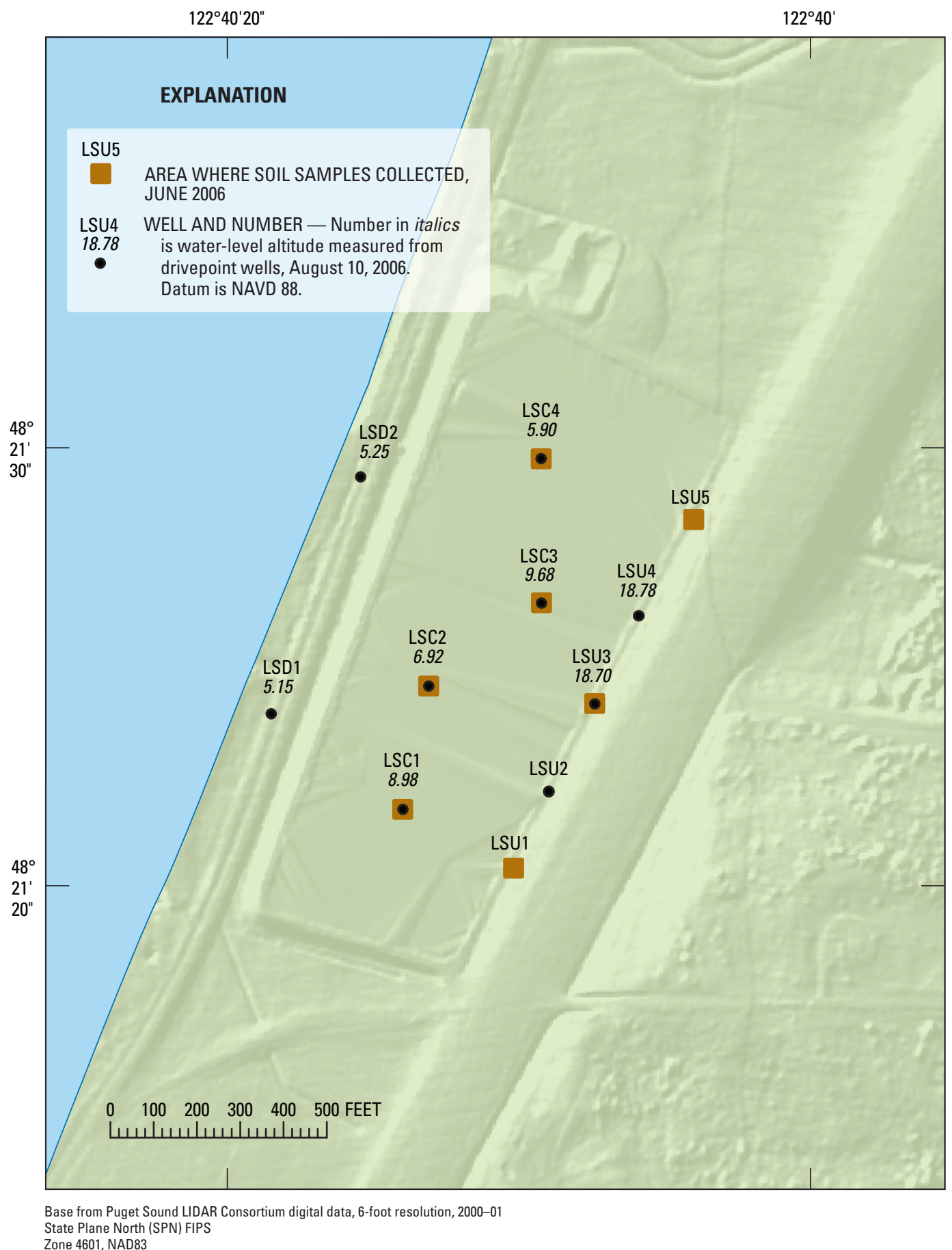

Figure 2. Location of drive-point wells, soil and sediment sampling sites, and water-level altitudes measured August 10, 2006 at the former sewage lagoon, Naval Air Station Whidbey Island, Washington. 
Samples collected for analysis of nutrients and chloride concentrations were filtered through a $0.45-\mu \mathrm{m}$ membrane filter into polyethylene bottles, chilled, and sent to the USGS National Water Quality Laboratory (NW Q L) in Lakewood, Colo. Chloride concentrations were analyzed using ion chromatography as described by Fishman and Friedman (1989). Nutrient concentrations were analyzed following procedures described by Fishman (1993) using colorimetric techniques with cadmium reduction and diazotization as appropriate. Concentrations of total nitrogen were determined colorimetrically using al kaline-persulfate digestion as described by Patton and K ryskalla (2003). Samples for total organic carbon analysis were collected in an amber glass bottle, chilled to less than $4^{\circ} \mathrm{C}$ and sent to the NW QL. Organic carbon concentrations were determined using high temperature combustion according to Standard M ethod 5310B as described by Franson (1992).

Soil samples were collected from four areas in the former lagoon (LSC1, LSC2, LSC 3, and LSC 4; fig. 2). In each sampling area, soil samples were collected from three depth intervals to determine the vertical extent of residual sewage sludge that might be present and potentially a source of nitrate contamination of ground water. The three depth intervals were $0-6,7-18$, and 19-30 in. B ased on the size of the berms surrounding the former sewage lagoon, the re-graded sediment material was not expected to provide more than 6 in. of additional mineral material to the land surface. The re-graded sediment would likely be thinnest al ong the central northsouth axis of the former sewage lagoon.

Composite sampling is used to evaluate soil nutrient concentrations (M ahler and Tindall, 1994; J acobson, 1999) because of the large degree of spatial variability that is present in soil nutrient concentrations (Stark 1994; Cain and others, 1999). For each of the three sampling depth intervals, a composite sample was collected by combining soil material obtained from five individual subsample cores. Subsamples were collected for compositing soil from five randomly selected locations within a 50 -ft diameter area of the center mark. A total of 12 composite samples were analyzed from the former sewage lagoon area.

For comparison to nitrogen concentrations in soil samples from the adjacent upgradient area of the former sewage lagoon, an additional set of composite samples were collected from the same three depth intervals. The upgradient composite sample consisted of soils collected from single subsample cores collected at soil sampling sites LSU 1, LSU3, and LSU 5 (fig. 2).
Q uality assurance and control included field and laboratory procedures. A nalyzing laboratories follow standard laboratory and quality-assurance procedures and participate in National proficiency testing programs. A $n$ inorganic blind sample monitoring program also is used at the USGS N ational Water Quality Laboratory to provide ongoing monitoring of laboratory generated water-quality data. Quality-control samples including a field blank and a field sample replicate also were submitted. Results from the field qual ity-assurance samples are shown in table 1. No substantial quality issues were identified in the results of those samples.

\section{Ground-Water Levels}

Water levels were measured in eight of nine drive-point wells installed in the former sewage lagoon and the immediate adjacent area (table 2 and fig. 2). The water level in well LSU 2 did not rapidly equilibrate with the aquifer after repeated surging. During installation of this drive-point well, silty material was observed $18 \mathrm{in}$. bel ow grade. Either the screen was clogged or the well screen was positioned in silt-clay material, thus ground-water level measurements from this well would not be useful.

Water-level data shown in figure 2 and table 1 were measured on the afternoon of A ugust 10, 2006, during low tide. Water levels were measured to coincide with low tide conditions to minimize any influence that tidal oscillation might have on the water-level measurements. The predicted low tide elevation for $A$ ugust 10 at Port Townsend was $-2.2 \mathrm{ft}$ at 11:47 a.m. (N ational O ceanic and A tmospheric A dministration, 2006). G round-water levels beneath the site of the former sewage lagoon were between the upgradient and downgradient locations. Water levels were highest al ong the upgradient eastern side of the former sewage lagoon and lowest on the western side nearest the shoreline of Puget Sound confirming that the direction of ground-water flow is toward the Puget Sound. Ground-water seepage from the former sewage lagoon can be expected to flow toward and discharge to Puget Sound (fig. 2). 
Table 1. Construction and water-level data for drive-point wells installed at the former sewage lagoon, Naval Air Station Whidbey Island, Washington, June and August 2006.

[Latitude and longitude coordinate information is referenced to the North A merican Vertical Datum of 1983 (NAD 83). A ltitude is referenced to National Geodetic Vertical Datum of 1929 (N GV D 29). Symbol:, -, water levels could not be measured. Abbreviations: dms, degrees minutes seconds; ft, foot; in., inch]

\begin{tabular}{|c|c|c|c|c|c|c|c|c|c|}
\hline $\begin{array}{l}\text { Site and } \\
\text { No. }\end{array}$ & $\begin{array}{l}\text { Latitude } \\
\text { (dms) }\end{array}$ & $\begin{array}{l}\text { Longitude } \\
\text { (dms) }\end{array}$ & $\begin{array}{l}\text { Land-surface } \\
\text { altitude } \\
\text { (ft) }\end{array}$ & $\begin{array}{l}\text { Casing } \\
\text { diameter } \\
\text { (in.) }\end{array}$ & $\begin{array}{l}\text { Well depth } \\
\text { (ft below } \\
\text { land surface) }\end{array}$ & $\begin{array}{c}\text { Height of } \\
\text { measuring } \\
\text { point } \\
\text { (ft above } \\
\text { land surface) }\end{array}$ & $\begin{array}{c}\text { Water-level } \\
\text { measurement } \\
\text { date }\end{array}$ & $\begin{array}{l}\text { Water level } \\
\text { (ft below } \\
\text { land surface) }\end{array}$ & $\begin{array}{l}\text { Water-level } \\
\text { altitude } \\
\text { (ft) }\end{array}$ \\
\hline \multicolumn{10}{|c|}{ Upgradient wells } \\
\hline LSU2 & 482122.1 & 1224009.1 & 24.16 & 0.5 & 8.9 & 1.70 & $\begin{array}{l}08-02-06 \\
08-10-06\end{array}$ & $\begin{array}{l}\text { Plugged } \\
\text { Plugged }\end{array}$ & - \\
\hline LSU3 & 482124.1 & 1224007.5 & 24.29 & .5 & 9.2 & 1.45 & $\begin{array}{l}06-28-06 \\
08-02-06 \\
08-10-06\end{array}$ & $\begin{array}{l}4.41 \\
5.34 \\
5.59\end{array}$ & $\begin{array}{l}19.88 \\
18.95 \\
18.70\end{array}$ \\
\hline LSU 4 & 482126.1 & 1224006.0 & 23.87 & .5 & 9.6 & 0.92 & $\begin{array}{l}06-26-06 \\
06-28-06 \\
08-02-06 \\
08-10-06\end{array}$ & $\begin{array}{l}5.97 \\
5.52 \\
4.69 \\
5.09\end{array}$ & $\begin{array}{l}17.90 \\
18.35 \\
19.18 \\
18.78\end{array}$ \\
\hline \multicolumn{10}{|c|}{ Lagoon wells } \\
\hline LSC 1 & 482121.7 & 1224014.1 & 16.32 & 0.5 & 9.1 & 1.50 & $\begin{array}{l}06-26-06 \\
06-28-06 \\
08-02-06 \\
08-10-06 \\
08-16-06\end{array}$ & $\begin{array}{l}7.15 \\
7.17 \\
7.27 \\
7.34 \\
7.39 \\
\end{array}$ & $\begin{array}{l}9.17 \\
9.15 \\
9.05 \\
8.98 \\
8.93\end{array}$ \\
\hline LSC2 & 482124.5 & 1224013.2 & 15.81 & .5 & 9.7 & 0.89 & $\begin{array}{l}06-28-06 \\
08-02-06 \\
08-10-06\end{array}$ & $\begin{array}{l}8.90 \\
8.92 \\
8.89\end{array}$ & $\begin{array}{l}6.91 \\
6.89 \\
6.92\end{array}$ \\
\hline LSC3 & 482126.4 & 1224009.3 & 17.00 & .5 & 15 & .35 & $\begin{array}{l}06-28-06 \\
08-02-06 \\
08-10-06 \\
08-16-06\end{array}$ & $\begin{array}{l}7.00 \\
7.25 \\
7.32 \\
7.52\end{array}$ & $\begin{array}{r}10.00 \\
9.75 \\
9.68 \\
9.48\end{array}$ \\
\hline LSC 4 & 482129.7 & 1224009.3 & 16.41 & .5 & 15 & 3.90 & $\begin{array}{l}06-28-06 \\
08-02-06 \\
08-10-06 \\
08-16-06\end{array}$ & $\begin{array}{r}\text { dry } \\
10.64 \\
10.51 \\
10.70\end{array}$ & $\begin{array}{l}- \\
5.77 \\
5.90 \\
5.71\end{array}$ \\
\hline \multicolumn{10}{|c|}{ Downgradient wells } \\
\hline LSD 1 & 482123.9 & 1224018.6 & 15.50 & 0.5 & 13 & 3.25 & $\begin{array}{l}08-02-06 \\
08-10-06 \\
08-16-06\end{array}$ & $\begin{array}{l}10.66 \\
10.35 \\
10.46\end{array}$ & $\begin{array}{l}4.84 \\
5.15 \\
5.04\end{array}$ \\
\hline LSD2 & 482129.3 & 1224015.5 & 15.16 & .5 & 13 & 2.62 & $\begin{array}{l}08-02-06 \\
08-10-06 \\
08-16-06\end{array}$ & $\begin{array}{r}10.52 \\
9.91 \\
10.46\end{array}$ & $\begin{array}{l}4.64 \\
5.25 \\
4.70\end{array}$ \\
\hline
\end{tabular}


Table 2. Ground-water quality data collected from drive-point wells at the former sewage lagoon at Naval Air Station Whidbey Island, Washington, June and August 2006.

[Total nitrogen: Nitrate plus nitrite plus ammonia plus organic nitrogen. Abbreviations and symbols: $\mathrm{mg} / \mathrm{L}$, milligram per liter; $\mu \mathrm{S} / \mathrm{cm}$, microseimen per centimeter. D, data censored (rejected) by laboratory; rep, field replicate sample; E, estimated value; <, actual value is less than value shown; >, actual value is greater than value shown; , approximate value; -, no data]

\begin{tabular}{|c|c|c|c|c|c|c|c|c|c|c|c|c|}
\hline $\begin{array}{c}\text { Site } \\
\text { and No. }\end{array}$ & $\begin{array}{c}\text { Date } \\
\text { sampled }\end{array}$ & $\begin{array}{c}\text { Dissolved } \\
\text { oxygen } \\
\text { (mg/L) }\end{array}$ & $\begin{array}{c}\text { Specific } \\
\text { conductance } \\
(\mu \mathrm{S} / \mathrm{cm})\end{array}$ & $\begin{array}{l}\text { Ferrous } \\
\text { iron } \\
(\mathrm{mg} / \mathrm{L})\end{array}$ & $\begin{array}{c}\text { Chloride } \\
\text { (mg/L) }\end{array}$ & $\begin{array}{c}\text { Ammonia } \\
\text { (mg/L } \\
\text { as } N \text { ) }\end{array}$ & $\begin{array}{l}\text { Nitrite plus } \\
\text { nitrate } \\
\text { (mg/L as } N \text { ) }\end{array}$ & $\begin{array}{c}\text { Nitrite } \\
\text { (mg/L as N) }\end{array}$ & $\begin{array}{c}\text { Total } \\
\text { nitrogen } \\
\text { (mg/L as } \mathrm{N})\end{array}$ & $\begin{array}{c}\text { Ortho- } \\
\text { phosphate } \\
\text { (mg/L } \\
\text { as P) }\end{array}$ & $\begin{array}{c}\text { Total } \\
\text { organic } \\
\text { carbon } \\
\text { (mg/L) }\end{array}$ & $\begin{array}{c}\text { Carbon } \\
\text { dioxide } \\
(\mathrm{mg} / \mathrm{L})\end{array}$ \\
\hline \multicolumn{13}{|c|}{ Upgradient wells } \\
\hline LSU 3 & $06-28-06$ & - & 575 & 34.8 & - & 3.85 & E0.05 & 0.017 & 5.49 & 0.134 & 72.5 & 70 \\
\hline LSU 4 & $06-28-06$ & - & 2,510 & - & - & - & - & - & - & - & - & - \\
\hline \multicolumn{13}{|c|}{ Lagoon centerline wells } \\
\hline LSC1 & $\begin{array}{l}06-28-06 \\
08-16-06\end{array}$ & $\begin{array}{l}0.1 \\
-\end{array}$ & $\begin{array}{r}808 \\
-\end{array}$ & $\begin{array}{c}11.5 \\
-\end{array}$ & $\begin{array}{r}- \\
61\end{array}$ & $\begin{array}{l}3.07 \\
4.23\end{array}$ & $\begin{array}{l}<0.06 \\
<0.06\end{array}$ & $\begin{array}{l}0.002 \\
0.004\end{array}$ & $\begin{array}{l}3.73 \\
4.82\end{array}$ & $\begin{array}{l}D \\
D\end{array}$ & $\begin{array}{c}14.7 \\
-\end{array}$ & $\begin{array}{c}250 \\
-\end{array}$ \\
\hline $\mathrm{LSC} 2$ & $06-28-06$ & - & 553 & 12.0 & - & 7.67 & $<0.06$ & $<0.002$ & 8.44 & 0.016 & 20.1 & $\sim 100$ \\
\hline \multicolumn{13}{|c|}{ Downgradient wells } \\
\hline LSD 1 & $\begin{array}{l}08-10-06 \\
08-16-06\end{array}$ & $\begin{array}{l}<0.1 \\
<0.1\end{array}$ & $\begin{array}{l}661 \\
650\end{array}$ & $\begin{array}{c}20.3 \\
-\end{array}$ & $\begin{array}{c}- \\
51.4\end{array}$ & $\begin{array}{l}3.79 \\
3.77\end{array}$ & $\begin{array}{l}<0.06 \\
<0.06\end{array}$ & $\begin{array}{l}0.005 \\
0.004\end{array}$ & $\begin{array}{l}4.29 \\
4.38\end{array}$ & $\begin{array}{l}0.807 \\
0.639\end{array}$ & $\begin{array}{c}13.6 \\
-\end{array}$ & $\begin{array}{c}145 \\
-\end{array}$ \\
\hline LSD2 & $\begin{array}{l}08-10-06 \\
08-16-06\end{array}$ & $\begin{array}{l}<0.1 \\
<0.1\end{array}$ & $\begin{array}{l}560 \\
573\end{array}$ & $\begin{array}{c}36.3 \\
-\end{array}$ & 38.5 & $\begin{array}{r}0.814 \\
E 0.869\end{array}$ & $\begin{array}{l}<0.06 \\
<0.06\end{array}$ & $\begin{array}{l}0.004 \\
0.002\end{array}$ & $\begin{array}{l}1.15 \\
1.20\end{array}$ & $\begin{array}{l}0.053 \\
0.021\end{array}$ & $\begin{array}{c}13.7 \\
-\end{array}$ & $\begin{array}{c}140 \\
-\end{array}$ \\
\hline LSD2 (rep) & 08-16-06 & - & - & - & - & E0.864 & $<0.06$ & 0.003 & 1.20 & 0.031 & - & - \\
\hline \multicolumn{13}{|c|}{ Field sample process blank } \\
\hline LSU 4 & $08-10-06$ & $>1$ & 2.2 & 0.0 & - & 0.014 & $<0.06$ & $<0.002$ & $<0.06$ & $<0.006$ & $<0.4$ & - \\
\hline
\end{tabular}

\section{Ground-Water Quality}

Concentrations of nitrate and selected other constituents in ground-water samples collected in June and A ugust 2006 are shown in table 1. Only five of the nine drive-point wells installed in the former sewage lagoon were capable of producing sufficient volume of ground water for sampling. As previously described, the well at site LSU 2 was too silty to provide useful water-level measurements or collection of ground-water samples. Wells at sites LSC 3 and LSC2 were initially incapable of producing more than 2 milliliters of water per minute, so the well points were extracted following the A ugust 10 water-level measurement and a 6 -in. length of stainless steel screen attached to 3/8-in. polyethylene tubing was installed using a retractable-open casing with a removable drive point. The stainless steel screens provided a greater area of well opening for flow of ground water into the well, but sampling was still unsuccessful. Fragments of peat material were removed from the well at site LSC 3 when the stainless steel well screen was extracted, and additional fragments of peat were extracted from the well at site LSC4 during subsequent probing. Hydraulic characteristics of peat include low permeability and high capacity for water retention (Price, 1997). The occurrence of peat in the areas near the well screen of wells at sites LSC 3 and LSC 4 was consistent with the observed drainage of the water during well development and the subsequent lack of yield when the well was pumped. A lthough the number of wells sampled was less than planned, the variability in the measured concentrations was small suggesting these samples generally are representative of ground water beneath the former lagoon area.

Concentrations of nitrogen species in ground water beneath the fomer lagoon were small with respect to the U.S. Environmental Protection A gency's (USE PA) maximum contaminant level $(M C L)$ of $10 \mathrm{mg} / \mathrm{L}$ for nitrate in ground water. Concentrations of nitrate measured in ground-water samples were less than the laboratory reporting limit of $0.06 \mathrm{mg} / \mathrm{L}$, although other forms of nitrogen more compatible with reducing geochemical conditions that were present in the 
ground water were measured. Concentrations of total nitrogen, which is the sum of nitrate, nitrite, ammonia, and organic nitrogen, ranged from 1.15 to $8.44 \mathrm{mg} / \mathrm{L}$ as N. M ost of the total nitrogen present in the ground-water samples was in the ammonia form, typically comprising 70 to 90 percent of the total nitrogen. Organic nitrogen was not measured directly but was cal culated as the difference between the concentration of total nitrogen minus the inorganic forms nitrate, nitrite, and ammonia. If all forms of nitrogen were converted to nitrate, the resulting concentration would remain smaller than the USEPA maximum contaminant level for nitrate. Specific conductance and chloride concentrations of ground water beneath the lagoon were larger than those reported for regional ground waters of Whidbey Island (Sapik and others, 1988) but were within the range of concentrations typical for treated municipal wastewaters ( $\mathrm{N}$ ational Research Council, 1996). For conservative constituents, such as chloride and specific conductance, ground water beneath the former sewage lagoon exhibited some effects of seepage from the former sewage lagoon but did not contain nitrogen concentrations greater than the maximum contaminant level.

Strongly reducing geochemical conditions in groundwater samples from beneath the former sewage lagoon were indicated by the absence of dissolved oxygen and nitrate and the presence of large concentrations of ferrous iron. R educing conditions commonly are observed in ground waters with abundant labile organic carbon such as from peat deposits, septic systems, or sewage lagoons. Total organic carbon (TOC) concentrations measured in ground water from beneath the former sewage lagoon ranged from 13.6 to $72.5 \mathrm{mg} / \mathrm{L}$. The largest TOC concentration was measured at the upgradient well at site LSU 3. L arge concentrations of TOC in ground water are characteristic of the occurrence of peat within aquifer materials. Given the abundant supply of organic carbon in ambient ground water at the site, any nitrate that may leach from residual sludge at the former sewage lagoon is expected to be quickly denitrified or transformed to nitrite or ammonia under the strongly reducing geochemical conditions that are present.

\section{Nitrogen in Soils and Sediment}

Concentrations of total nitrogen in all soil and sediment samples from the former sewage lagoon were small ( $<100$ to $330 \mathrm{mg} / \mathrm{kg}$; table 3) compared to concentrations (1,200 mg/kg as $\mathrm{N}$ or about 5,000 lb/acre) that are typical for well developed agricultural soils in the Puget-Willamette region west of the Cascade M ountains (M arx and others, 1999) and substantially less than 3 percent $(30,000 \mathrm{mg} / \mathrm{kg})$ that is the typical concentration of nitrogen in sewage sludge (National Research
Council, 1996). Nitrate-nitrogen concentrations measured in soils from the former sewage lagoon were in the range considered small (less than $10 \mathrm{mg} / \mathrm{kg}$ ) for typical soils west of the $C$ ascades and ammonia-nitrogen concentrations were more in the typical range of $2-10 \mathrm{mg} / \mathrm{kg}$. The largest nitrate and ammonia concentrations, 14 and $24 \mathrm{mg} / \mathrm{kg}$ respectively, were measured in soil samples from the two lower depth intervals at sampling site LSC1 in the former sewage lagoon and may represent the downward migration of nitrogen in that area. The lack of substantial accompanying organic carbon indicates that measured nitrogen was not due to the presence of buried organic matter. Nitrate and ammonia al so were detected in the sediments from lower depth intervals beneath the upgradient locations at concentrations approaching 25 to 50 percent of those beneath the former sewage lagoon. Total nitrogen concentrations in soil samples from the top and middle depth intervals at the upgradient locations were larger than those in the samples from the former sewage lagoon.

Table 3. Nitrogen and organic carbon concentrations in composite soil and sediment samples collected and analyzed by the U.S. Navy at the former sewage lagoon, Naval Air Station Whidbey Island, Washington, June 2006.

\begin{tabular}{|c|c|c|c|c|c|}
\hline \multirow{2}{*}{$\begin{array}{c}\text { Site } \\
\text { and No. }\end{array}$} & \multirow{2}{*}{$\begin{array}{c}\text { Sample } \\
\text { location }\end{array}$} & \multicolumn{3}{|c|}{$\begin{array}{l}\text { Concentration, in } \\
\text { milligrams per kilogram }\end{array}$} & \multirow{2}{*}{$\begin{array}{c}\text { Organic } \\
\text { carbon } \\
\text { (percent) }\end{array}$} \\
\hline & & $\begin{array}{l}\text { Nitrate as } \\
\text { nitrogen }\end{array}$ & $\begin{array}{c}\text { Ammonia as } \\
\text { nitrogen }\end{array}$ & $\begin{array}{c}\text { Total } \\
\text { nitrogen }\end{array}$ & \\
\hline \multicolumn{6}{|c|}{ Depth interval, 0-6 inches } \\
\hline LSC1 & Lagoon & 1 & 2 & $<100$ & 0.2 \\
\hline LSC2 & Lagoon & 1 & 2 & $<100$ & 0.3 \\
\hline LSC3 & Lagoon & 1 & 2 & $<100$ & 0.2 \\
\hline $\mathrm{LSC} 4$ & Lagoon & 1 & 3 & 330 & 0.8 \\
\hline LSU 1,3,5 & Upgradient & 1 & 2 & 430 & 1 \\
\hline \multicolumn{6}{|c|}{ Depth interval, 7-18 inches } \\
\hline $\mathrm{LSCl}$ & Lagoon & 14 & 6 & $<100$ & 0.2 \\
\hline LSC2 & Lagoon & 4 & 9 & $<100$ & 0.2 \\
\hline LSC3 & Lagoon & 1 & 2 & $<100$ & 0.2 \\
\hline LSC 4 & Lagoon & 1 & 2 & $<100$ & 0.2 \\
\hline LSU 1,3,5 & Upgradient & 1 & 3 & 270 & 0.6 \\
\hline \multicolumn{6}{|c|}{ Depth interval, 19-30 inches } \\
\hline $\mathrm{LSC} 1$ & Lagoon & 9 & 24 & $<100$ & 0.2 \\
\hline LSC2 & Lagoon & 2 & 7 & $<100$ & 0.2 \\
\hline LSC3 & Lagoon & 1 & 4 & $<100$ & 0.2 \\
\hline LSC4 & Lagoon & 1 & 5 & $<100$ & 0.2 \\
\hline LSU $1,3,5$ & Upgradient & 3 & 13 & $<100$ & 0.3 \\
\hline
\end{tabular}


The measured organic carbon fractions ranged from 0.2 to 1 percent (table 3 ), which were less than the 2 to 5 percent that is typical for soils developed on glacial outwash. There was little organic carbon or nitrogen measured in the composite soil samples from the former sewage lagoon indicating the amount of residual sewage sludge present in the sediments was small. During sample collection in J une 2006, no discernible organic layer within the soil profile was observed nor was there visual evidence of sewage-sludge or residual organic material. Stands of clover, lupine, and rye-grass were established and growing during J une 2006, but were withered during A ugust of the same year. There was no apparent soil profile observed at the sampling locations within the former sewage lagoon. A the upgradient sampling locations, poorly developed profiles consisting of a layer of slightly oxidized surficial sediments were present in the upper few inches.

Concentrations of nitrogen measured in soil samples collected in J une 2006 were less than the concentrations reported for the soil samples collected in A ugust 2005. A likely cause of this difference could have resulted from differences in the depth interval over which the samples were collected. M ost of the organic matter that was visible in the sediments from the site was observed near the soil surface, which is consistent with natural soils where the largest concentrations of soil nitrogen typically are found in organic matter occurring near the soil surface (B rady, 1974; B ohn and others, 1984). Information was not available on the depth interval used in the collection of soil samples in A ugust 2005. Samples collected in J une 2006 integrated soil material from intervals of $6 \mathrm{in}$. or more of the soil-sediment profile and may have included a much larger fraction of the non-organic rich soil material that essentially diluted the nutrient contribution from the more organic rich soil from near the land surface thus resulting in substantially smaller concentrations of soil nutrients. The June 2006 soil samples clearly show the absence of extensive residual sewage sludge in the sampled soils.

B ased on the relatively small concentrations of organic carbon and nitrogen species measured in soil samples integrated over the approximately $30 \mathrm{in}$. profile from the former sewage lagoon (table 3 ), little residual sewage sludge remains in the re-graded sediments and soil overlying the area. The smallest concentrations of both total nitrogen and organic carbon were measured in the deepest depth interval sampled (19-30 in.) within the former lagoon indicating that any residual sewage sludge is expected to be above that depth.

\section{Assessment of Potential for Ground- Water Contamination}

Concentrations of nitrogen species in ground-water samples from beneath the former sewage lagoon obtained after the first season of winter rains following deconstruction and restoration of the former sewage lagoon were less than the maximum contaminant level. M ultiple lines of evidence, including (1) the lack of substantial measurable quantities of organic matter in the re-graded sediments; (2) agronomic analysis of nutrient uptake by plants and the potential sequestration of nitrogen in the developing soil at the site; and (3) the possible occurrence of peat deposits within the aquifer material, indicate that the potential for substantial additions of nitrogen to ground water beneath the former sewage lagoon resulting from its deconstruction is small.

The lack of measurable quantities of total nitrogen and organic carbon in the composite soil-sediment samples indicate the lack of substantial organic matter or residual sewage sludge that could serve as a nitrogen source in the re-graded sediments. The amount of total nitrogen in the soil samples is used as a factor in the agronomic analysis that is used to assess potential for ground-water contamination at sites where land application of biosolids is practiced (Washington State Department of Ecology, 2000). The analysis considers the conversion of nitrogen bound in organic matter from biosolids or sewage sludge to forms that are mobile and available for either plant uptake or leaching to ground water. Nitrogen is released over several years from the organic matter in biosolids or sewage sludge although the rate of release decreases with time (Gilmour and others, 2003). U sing worksheets for calculating agronomic biosolidapplication rates in Washington (Cogger and Sullivan, 1999), an estimated 30 percent of the nitrogen present in land-applied biosolids is converted to plant-available nitrogen (nitrate or ammonia) in the first year following application. In the second and third year, the amount of nitrogen converted to plant available forms decreases to 8 and 3 percent, respectively, and in the years following, only 1 percent of the nitrogen in original application of biosolids is converted to plant available or leachable forms. Following year five, residual organic matter is considered part of the stable soil organic matter and are not included in subsequent calculations. Thus, the potential for nitrogen contamination of ground water arising from residual sewage sludge will diminish commensurately with time. 
A pplying the agronomic analysis approach (Cogger and Sullivan, 1999) to determine the amount of nitrogen that might be present at the NA SW I former sewage lagoon and might be released from any remaining residual sewage sludge is complicated by several factors. First, the total amount of nitrogen present in the surficial soil sediments of the former sewage lagoon is difficult to estimate quantitatively because more than one-half of the laboratory analysis results were less than the reporting limit of $100 \mathrm{mg} / \mathrm{kg}$. A nd secondly, the sediments in question constitute a very poorly developed soil and may have substantially different nutrient release and uptake rates than those determined for w ell-developed agronomic soils. In addition, crop nutrient requirements are a component of the analysis, and the lack of established vegetation at the site further complicates the analysis. Lastly, because the former lagoon soils are not well developed, much of the nitrogen converted from any residual sludge to plant available forms likely will be sequestered in developing plant and soil bacteria, as is common in soils developed on river terraces and sand bars (K aye and others, 2003).

The potential for leaching of nitrogen to ground water is greatest at times when the temporal and spatial vegetative cover at the former lagoon is sparse and plants are not present to utilize available forms of nitrogen. A $n$ estimation of the nitrogen concentration that might occur in recharge that has leached all available nitrogen from the soil can be calculated. The plausible estimation of maximum concentration of nitrogen (both nitrate and ammonia) in recharge water passing through and leaching all available nitrogen from the upper 6 in. portions of the re-graded sewage lagoon area can be calculated based on the maximum measured total nitrogen concentration of $330 \mathrm{mg} / \mathrm{kg}$, a soil density of $1.5 \mathrm{~g} / \mathrm{cm}^{3}$, a recharge rate of $11.8 \mathrm{in} / \mathrm{yr}$ (equival ent to $0.03 \mathrm{~L} / \mathrm{cm}^{2}$ ), and the organic nitrogen mineralization rates provided in a worksheet for calculating bio-solids application rate (Cogger and Sullivan, 1999). The resulting combined concentration of nitrate and ammonia in the recharge water leaching all available nitrogen from the upper $6 \mathrm{in}$. of the soil zone would be:

Year $174.0 \mathrm{mg} / \mathrm{L}$ combined nitrate and ammonia

Year $219.8 \mathrm{mg} / \mathrm{L}$ combined nitrate and ammonia

Y ear $37.42 \mathrm{mg} / \mathrm{L}$ combined nitrate and ammonia

Year $42.48 \mathrm{mg} / \mathrm{L}$ combined nitrate and ammonia

Year $52.48 \mathrm{mg} / \mathrm{L}$ combined nitrate and ammonia
The amount of nitrate-nitrogen that would be transported to ground water beneath the former sewage lagoon is unknown; however, concentrations would be expected to be less than the estimated concentration of the recharge leachate. The recharge water containing the leached nitrogen contains both ammonia and nitrate species. M ost of the nitrogen in the recharge leachate likely was in the ammonia form as the concentration of ammonia typically was at least twice as large as nitrate in the soil sediments that were analyzed and 70 to 90 percent of the total nitrogen present in ground-water samples from the site was in the ammonia form. In addition, the recharge-leachate would mix with ambient ground water that typically contains less than $0.5 \mathrm{mg} / \mathrm{L}$ nitrate (Sapik and others, 1988). B ecause the area is near the shoreline of Puget Sound, tidal influence on ground water is expected to cause daily oscillation of ground-water levels that would increase mixing of local recharge with regional ground water. $M$ ixing of the limited amount of recharge reaching the water table at any one time is likely to result in substantial dilution of concentrations of nitrogen species.

During well installation, peat material was observed in the sediments at wells at sites LSC 3 and LSC 4 and its presence within the aquifer material may contribute to reductions in the concentrations of nitrogen species in recharge leachate and ground water. Wetlands and peat deposits have been used in the treatment of wastewater to reduce nutrient concentrations as well as many other potential contaminant in domestic and municipal wastewaters (Couillard, 1994; Verhoevan and M euleman, 1999). The extent of peat deposits in not known; however, soils in the vicinity of the former sewage lagoon were mapped as Rifle or Tanawax peat soils (Ness and Richins, 1958).

\section{Summary and Conclusions}

The potential for contamination of ground water from residual sewage sludge in re-graded sediments following deconstruction and site restoration of a sewage lagoon was evaluated. Composite soil and sediment samples were collected and analyzed for organic carbon and nitrogen species, ground-water levels were measured in temporary drive-point wells, and ground-water samples were collected and analyzed for nutrients and other water-quality characteristics. Wells were located in three areas based on the anticipated direction of ground-water flow toward the beach. 
Resulting water-level measurements indicate the direction of ground-water flow is toward the Puget Sound. Prior to the installation of temporary wells, composite soil samples were collected by the U.S. N avy and analyzed to determine the dryweight concentration of organic carbon and nitrogen species.

The amount of total nitrogen and organic carbon present in the sediments at the former sewage lagoon was only about 25 percent of the amount typically present in developed agricultural soils, indicating that the sediment of the former lagoon area is essentially devoid of organic matter that would be present in residual sewage sludge. The largest concentration of total nitrogen measured in soil samples from the former lagoon (330 milligrams per kilogram) was used to develop an upper-bound estimate of the amount of nitrogen that might be leached by recharge and mixed with ground water. Nitrate concentrations measured in groundwater samples were smaller than the upper-bound estimate and did not exceed established U.S. Environmental Protection A gency's maximum contaminant level of 10 milligrams per liter. Seventy to 90 percent of the total nitrogen present in ground water was in the ammonia form with a maximum concentration of 7.67 milligrams per liter.

Overall, concentrations of nitrogen species in ground water beneath the lagoon were small with respect to the U.S. Environmental Protection A gency maximum contaminant level for nitrate in ground water (10 milligrams per liter). Concentrations of total nitrogen in ground water beneath the lagoon, which is the sum of all forms of nitrogen including nitrate, nitrite, ammonia, and organic nitrogen, ranged from 1.15 to 8.44 milligrams per liter as $\mathrm{N}$. Thus, even if all forms of nitrogen were converted to nitrate, the combined mass of nitrogen would be less than referenced as the maximum contaminant level. Given the abundant supply of organic carbon in ambient ground water at the site, any nitrate that may leach from residual sludge at the former sewage lagoon is expected to quickly transform to nitrite and ammonia under the strongly reducing geochemical conditions that are present.

\section{Acknowledgments}

The authors thank Calvin Canton of NA SW I provided funding and logistical support for field activities. M att J abloner of the $\mathrm{N}$ aval Facilities Engineering Command, N orthwest provided field assistance and collections of soil nitrogen and carbon data. Greg J ustin and J ohnna Higgins of the U.S. Geological Survey provided field assistance with well installation and field surveying.

\section{References Cited}

B rady, N.C., 1974, The Nature and Properties of Soil, 8th ed.: $\mathrm{N}$ ew York, M acM illian Publishing C0., 639 p.

Bohn, H.L., M cNeal, B.L., and O'C onnor, G .A ., 1985, Soil Chemistry, 2nd ed.: N ew York, John Wiley and Sons, 341 p.

Cain, M .L., Subler, Scott, Evans, J.P., and Fortin, M .J ., 1999, Sampling spatial and temporal variation in soil nitrogen availability: Oecologia, v. 118, p. 397-404.

Cogger, C.G. and Sullivan, D.M., 1999, Worksheet for calculating biosolids application in agriculture. PNW 511w. Washington State U niversity Cooperative Extension.

Couillard, D., 1994, The use of peat in waste water treatment: Water Research v. 28, no.6., p 1261-1279.

Fishman, M.J., ed., 1993, M ethods of analysis by the U.S. Geological Survey National Water Quality L aboratoryDetermination of inorganic and organic constituents in water and fluvial sediments: U.S. Geological Survey OpenFile R eport 93-125, $217 \mathrm{p}$.

Fishman, M .J ., and Friedman, L.C., 1989, M ethods for determination of inorganic substances in water and fluvial sediments: U.S. Geological Survey Techniques of WaterResources Investigations, book 5, chap. A 1, 545 p.

Franson, M.H., ed. 1992, Standard methods for the examination of water and wastewater $\left(18^{\text {th }} \mathrm{ed}\right.$.): Washington, D.C., A merican Public Health A ssociation, A merican Water Works A ssociation, and Water Environment Federation, variously paginated.

Gilmour, J.T., Cogger, C.G., Jacobs, L.W., Evanylo, G.K., and Sulivan D.M., 2003, Decomposition and Plant-Avaliable Nitroge in Biosolids: Laboratory Studies, Field Studies, and Computer Simulation: J ournal of Environmental Quality, v. 32, p. 1498-1507.

Hach Company, 1998, DR/2010 Spectrophotometer Procedures M anual: Hach Company, Loveland, Colo.

J acobson, J.S., 1999, Soil sampling: M ontana State U niversity Extension Service, M T-8602,

K aye, J.P., Binkley, Dan, and Rhoades, Charles, 2003, Stable soil nitrogen accumulation and flexible organic matter stoichiometry during primary floodplain succession: Biogeochemistry, v. 63, p. 1-22. 
M ahler, R.L., and Tindall, T.A., 1994, Soil sampling, University of I daho Cooperative Extension System, Bulletin $704,8 p$.

M arx, E.S., Hart, John, and Stevens, R.G ., 1999, Soil test interpretation guide: Oregon State U niversity Extension Service, EC 1478, Corvallis, Oregon, 8 p.

National Oceanic and A tmospheric A dministration, 2006, Tides and currents, accessed A pril 12, 2007, at http:II tidesandcurrents.noaa.gov.

National Research Council, 1996, U se of reclaimed water and sludge in food crop production: National A cademy Press, Washington, D.C., 192 p.

Ness, A.O., and Richins, C.G., 1958, Soil Survey-Island County, Washington Series 1949, N o. 6: U.S. Department of A griculture-Soil Conservation Service, 58 p.

Patton, C.J ., and K ryskalla, J.R., 2003, M ethods of analysis by the U.S. Geological National Water Quality Laboratory: Evaluation of alkal ine persul fate digestion as an alternative to $\mathrm{K}$ jel dahl digestion for determination of total and dissolved nitrogen and phosphorus in water: U.S. Geological Survey Water-Resources Investigation Report 2003-4174, 33 p.

Price, J.S., 1997, Soil moisture, water tension, and water table relationships in a managed cutover bog: J ournal of Hydrology, v. 202, p. 23-32.

Riggs, G.B., 1958, Peat resources of Washington: Washington State Division of M ines and Geology, Bulletin N 0. 44, $272 p$.

Sapik, D.B., B ortleson, G.C., Drost, B.W., Jones, M .A ., and Prych, E.A., 1988, Ground-water resources and simulation of flow in aquifers containing freshwater and seawater, Island County, Washington: U.S. Geological Survey WaterResources Investigations Report 87-4182, 67 p.
Stark, J.M ., 1994, Causes of soil nutrient heterogeneity at different scales, in Caldwell, M.M ., and Pearcy, R.W. (eds.), Explotation of environmental heterogeneity by plants: E cological processes above and below ground: A cademic Press, N ew York, USA, p. 255-284.

URS Team, 1993, Remedial Investigation for Operable U nit 1, NA S W hidbey Island, Oak Harbor, Washington: Prepared by URS Consultants, Seattle, Wash., for Engineering Field A ctivity N orthwest, Silverdale, Wash., CTO N 0. 0005.

U.S. Geological Survey, 1997-2006, National field manual for the collection of water-quality data: U.S. Geological Survey Techniques of Water-Resources Investigations, book 9 . Chapters A 1-A 9, accessed A ugust 2006 at http://pubs. water. usgs.gov/twrigA; updates and revisions are ongoing and are summarized at http://water.usgs.gov/ow //FieldM anual/ mastererrata.html.

Vaccaro, J.J., Hansen, A .J ., and J ones, M .A ., 1998, Hydrogeologic framew ork of the Puget Sound A quifer System, Washington, B ritish Columbia: U.S. Geological Survey Professional Paper 1424-D, 77 p.

Verhoevan, J.T.A ., and M euleman, A.F.M ., 1999, Wetlands for wastewater treatment: Opportunities and limitations: Ecological Engineering, v. 12, p. 5-12.

Washington State Department of Ecology, 2000, B iosolids $M$ anagement Guidelines for Washington State: Publication \#93-80 R evised J uly 2000, http://www.puyallup.wsu.edul soilmgmt/B M G.htm. 
14 Nitrogen Species at a Former Lagoon: Naval Air Station Whidbey Island, Island County, Washington

Page is intentionally left blank 
Manuscript approved for publication, April 30, 2007

Prepared by the USGS Publishing Network,

Publishing Service Center, Tacoma, Washington

Bill Gibbs

Linda Rogers

Sharon Wahlstrom

Bobbie Jo Richey

For more information concerning the research in this report, contact the Director, Washington Water Science Center

U.S. Geological Survey, 934 Broadway - Suite 300

Tacoma, Washington 98402

http://wa.water.usgs.gov 


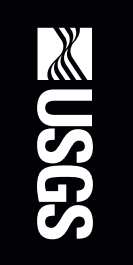

8
8
$x$
0
$\frac{0}{2}$
0
$\frac{1}{5}$
$\frac{0}{\omega}$

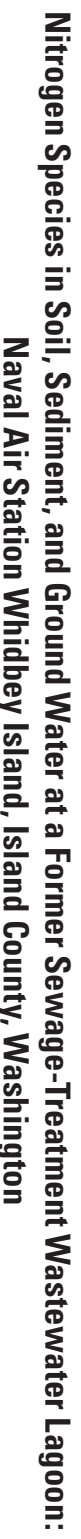

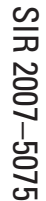

